\title{
Switching from a high-fat cellulose diet to a high-fat pectin diet reverses certain obesity-related morbidities
}

\author{
Julie K. Bray ${ }^{1}$, Gabriel S. Chiu, ${ }^{1,2}$, Leslie K. McNeil ${ }^{1}$, Morgan L. Moon ${ }^{1,2}$, Robyn Wall', Albert E. Towers ${ }^{1,2}$ \\ and Gregory G. Freund ${ }^{1,2,3,4^{*}}$ (D)
}

\begin{abstract}
Background: Reducing caloric intake is a proven intervention for mitigating and modulating morbidities associated with overnutrition. Caloric restriction is difficult to affect clinically, therefore, dietary interventions that ameliorate the adverse consequences of overnutrition in the presence of a high-calorie diet would be of value.

Methods: Mice were fed an obesogenic diet containing $60 \%$ fat $+10 \%$ cellulose (HFC), or a control diet containing $10 \%$ fat $+10 \%$ cellulose (LFC) for 12 wks. Subgroups of mice were then switched from HFC to each of the following diets for an additional 5 wks: 1) $60 \%$ fat $+10 \%$ pectin (HFP), 2) LFC or 3) $10 \%$ fat $+10 \%$ pectin (LFP). To test for statistical differences, one-way or two-way ANOVAs were used with or without repeated measurements as needed.

Results: In comparison to HFC, HFP prevented additional weight gain while LFC and LFP triggered weight loss of 22.2 and $25.4 \%$, respectively. Mice continued on HFC experienced a weight increase of $26 \%$ during the same 5 wk. interval. After 12 wks, HFC decreased mouse locomotion by $18 \%$ when compared to control diet, but a diet switch to LFC or LFP restored mouse movement. Importantly, HFP, LFC, and LFP reduced fasting blood glucose when compared to HFC. Likewise, HFP, LFC and LFP improved glucose tolerance and decreased fatty liver by 37.9, 49.8, 53.6 and 20.2\%, $37.2,43.7 \%$, respectively.
\end{abstract}

Conclusions: Taken together, the results indicate that the dietary fiber pectin can mitigate some adverse consequences of overnutrition even in the presence of high-fat.

\section{Background}

Obesity is a significant world-wide health problem that has more than doubled in incidence since 1980 [14, 25, 27]. According to the World Health Organization, obesity is projected to affect 1 in 5 people worldwide by 2025 [2]. Obesity is a critical risk factor in the development of type 2 diabetes [13, 24] and cancer [17, 71], likely tied to obesity-associated chronic inflammation, oxidative stress and hyperglycemia [16, 23, 28, 81]. Recently, obesity appears especially tied to non-alcoholic fatty liver disease (NAFLD) due, in a part, to high-fat diet-associated overnutrition [53, 85]. In clinical studies, the development of obesity is negatively associated with physical activity [62]

\footnotetext{
* Correspondence: freun@illinois.edu

'Department of Pathology, Program in Integrative Immunology and Behavior, University of Illinois, Urbana, IL, USA

${ }^{2}$ Division of Nutritional Sciences, University of Illinois, Urbana, IL, USA

Full list of author information is available at the end of the article
}

and positively correlated with fat intake [32]. Therefore, interventions that mitigate the ability of the body to utilize dietary fat might forestall obesity.

Dietary fibers have been proposed as an intervention against obesity [68]. Rationale for their use includes a demonstrated ability in humans to reduce appetite, energy intake, and body weight $[76,80]$. Dietary fibers (usually classified as soluble or insoluble) are generally carbohydrates from plants that resist digestion and absorption in the human small intestines [1]. Soluble fibers, such as gums, insulin-type fructans, and pectin, dissolve in water and are easily fermented by the microbiota of the large intestine [41]. Insoluble fibers, such as lignin and cellulose, do not dissolve in water and resist fermentation [41]. In terms of body weight regulation, both soluble and insoluble fibers can promote weight loss [33], but there is an inconsistent relationship between fiber solubility and its ability to reduce appetite 
and body weight ([20,44], Isken 2010). While soluble fiber can promote weight loss [12], other factors such as coincident fat intake [57] and calories inherent to the short-chain fatty acid fermentation products [26, 40, 77] can negate this salutary effect.

The soluble dietary fiber pectin positively impacts blood glucose regulation $[42,65]$, sparking interest in its application to diabetes prevention/treatment $[10,37,70]$. Pectin is a polysaccharide that is primarily found in citrus peels and is often used as a gelling agent in the food industry [74]. Previously, we demonstrated that dietary pectin, when compared to the insoluble fiber cellulose, sped recovery from endotoxin in a mouse model of sepsis [64]. Since cellulose is the main structural component in plants [67], it is generally the most consumed of the dietary fibers $[46,50]$. Pectin, in contrast, is consumed on a limited basis $[46,50]$ since it is a minority component of the edible parts of plants [63]. Previous studies have shown that pectin in conjunction with a HFD can reduce inflammation, cholesterol and liver fat $[36,78]$. Therefore, we compared the effectiveness of high and low fat diets in conjunction with cellulose and pectin with regard to modifying the impact of HFD-induced obesity in mice.

\section{Methods}

\section{Animals}

Animal use was conducted in accordance with Institutional Animal Care and Use Committee approved protocols at the University of Illinois. C57BL/6 J male animals were purchased from Jackson Laboratory (Bar Harbor, $\mathrm{ME})$ at 3 weeks of age. Mice were group housed (8 mice/cage) in standard shoebox cages (length $46.9 \mathrm{~cm}$; width $25.4 \mathrm{~cm}$; height $12.5 \mathrm{~cm}$ ) and allowed water and food ad libitum. After 11 weeks on diet, mice were individually housed in small shoebox cages (length $28.9 \mathrm{~cm}$; width $17.9 \mathrm{~cm}$; height $12.7 \mathrm{~cm}$ ) and acclimated for a week before switching to the new diets. Housing temperature $\left(72{ }^{\circ} \mathrm{F}\right)$ and humidity $(45-55 \%)$ were controlled as was a $12 / 12 \mathrm{~h}$ reversed dark-light cycle (2200-1000 h). Video recording of animal behavior was performed under red light using a Night Shot capable video camera (Sony HDR-XR500V). Except for body weight, food intake and locomotor activity, all treatments at all time-points represent separate cohorts of mice. The total number of mice utilized was 80 .

\section{Diets}

All diets were purchased from Research Diets (New Brunswik, NJ). Mice were fed open source uniform-base diets containing either $10 \%$ calories from fat with $100 \mathrm{~g}$ of cellulose (LFC, D06082201) or 60\% calories from fat with $100 \mathrm{~g}$ of cellulose (HFC, D07102501) starting at 4 weeks of age. LFC-fed mice were kept on the same diet to serve as control. After 12 weeks on diet, mice fed HFC were switched to either LFC, $10 \%$ calories from fat with $105 \mathrm{~g}$ of pectin (LFP, D06082202), 60\% of calories from fat with $105 \mathrm{~g}$ of pectin (HFP, D08111803), or HFC (Table 1).

\section{Body weight}

Mice were weighed weekly using the Adventurer Pro digital scale (Ohaus, Parisippany, NJ) as a repeated measure over time.

\section{Food intake}

Food intake was measured in individually-housed mice, as a repeated measure, as we have described [75]. In brief, food was moved from the overhead cage food hopper and placed in an $8 \mathrm{~cm}$ diameter $\times 5 \mathrm{~cm}$ stainless steel bowl in conjunction with replacing the bedding. After $24 \mathrm{~h}$, food intake was considered to be the difference between the weight of the bowl plus food at the beginning of the $24 \mathrm{~h}$ period and the weight of the bowl plus food and food recovered from the bedding after the $24 \mathrm{~h}$ period.

\section{Locomotion}

Spontaneous locomotor activity was measured, as a repeated measure, as we have described [11, 45, 87]. Mice were video recorded in their home cage for $5 \mathrm{~min}$. Distance moved was quantified using EthoVision XT 7.

\section{Glucose testing}

Blood glucose was measured as we have previously described [45] in mice that had fasted for $16 \mathrm{~h}$. For glucose tolerance testing, mice were injected i.p. with a $20 \%$ glucose solution equaling $1 \%$ of total body weight. Mouse tail blood glucose was recorded using a FreeStyle Freedom blood glucose monitor (Abbott, Abbott Park, IL) after the tail was cleaned with $70 \%$ ethanol and lanced with a sterile 18-gauge hypodermic needle (Franklin Lakes, NJ). Glucose was measured every $15 \mathrm{~min}$ for $90 \mathrm{~min}$ then every $30 \mathrm{~min}$ until $180 \mathrm{~min}$ post-injection. Results represent the total area under the curve of blood glucose versus time as calculated using the trapezoidal rule [72].

\section{Histochemistry}

As we have previously described [11, 38], mice were euthanized by $\mathrm{CO}_{2}$ asphyxiation. The mouse chest cavity was opened and the right atrium incised. Mice were perfused through the left ventricle with $30 \mathrm{mLs}$ of ice cold PBS using a 18 gauge needle and $30 \mathrm{~mL}$ syringe. Mice were next perfused with $30 \mathrm{mLs}$ of ice-cold $10 \%$ neutral buffered formalin. Harvested livers were additionally fixed in $10 \%$ neutral buffered formalin for $24 \mathrm{~h}$. Livers were subsequently paraffin embedded and 
Table 1 Nutrient composition of LFC, LFP, HFC and HFP

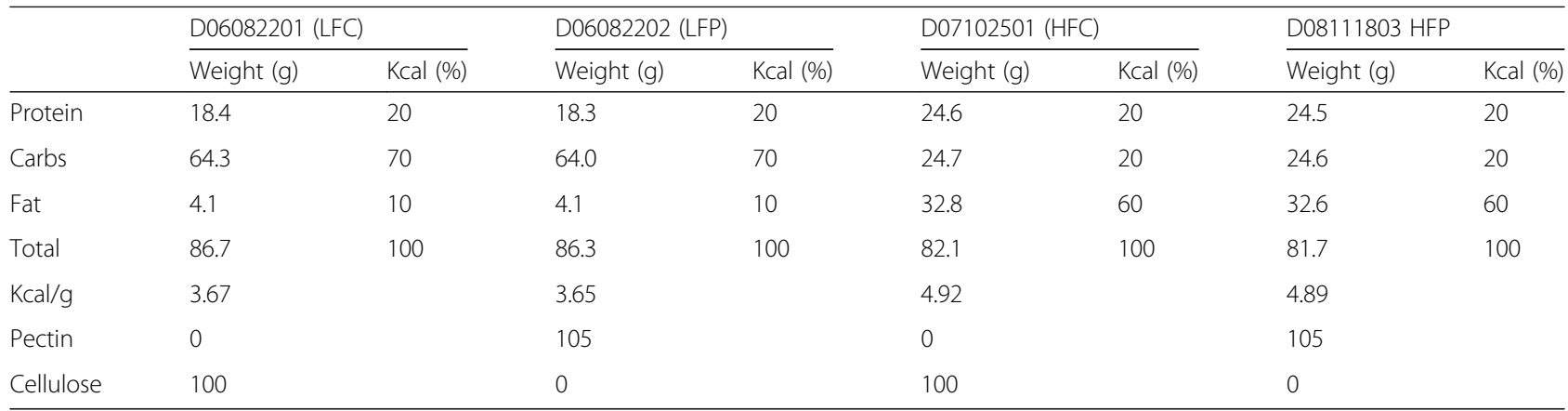

sectioned. Five micron section was stained with hematoxylin and eosin (H\&E) using an automated stainer (Sakura). Stained slides were imaged at $40 \times$ with a NanoZoomer 2.0-HT (Hamamatsu, Bridgewater, NJ). Percent of liver fat was determined using Image methods provided previously described (NIH) [3].

\section{Statistics}

All data are presented as mean \pm SEM. Data was analyzed using Sigma Plot 11.2 (Systat Software, Chicago, IL). To test for statistical differences, a one-way or two-way ANOVA was used with or without repeated measurements where needed. Tukey's test was used for post-hoc pair-wise multiple comparison procedures. Where indicated, raw data was transformed using a log10 transformation to attain equal variance. All statistical analysis included testing for time point $\mathrm{x}$ treatment interactions. Statistical significance was denoted at $p<0.05$.

\section{Results}

Switching from HFC to HFP prevents weight gain, while switching to LFC or LFP causes weight loss

To determine the effects of fat and fiber intake on diet-induced obesity, mice were fed a HFC diet for 12 weeks (baseline) then either maintained on the HFC diet or switched to HFP, LFC or LFP. As a control, a concurrent group of mice were fed LFC. Mice fed HFC for 12 weeks weighed significantly more than mice fed LFC (Table 2, $p<0.001$ ). After the diet switch, HFC mice gain weight (Table 2 , time effect of HFC, $p<0.001$ ) while mice switched to HFP did not gain weight (Table 2, time effect of HFP, $p=0.42$ ). In contrast, mice switched to either LFC or LFP lost weight (Table 2, time effect of LFC, $p<0.001$, time effect of LFP, $p<0.001)$. Interestingly, by 1 week post-diet switch, mice demonstrated weight loss (Tables 2, 1 wk. post-switch: main effect of fat, $p<0.001$, fiber, $p=0.01$ and interaction, $p=0.29$ ). In addition, the weight modulating effects of pectin and low fat diet were maintained for 5 weeks after diet switching (Tables 2) 2 wk. post-switch: main effect of fat, $p<0.001$, fiber, $p=0.002$ and interaction, $p=0.13$. 3 wk. post-switch: main effect of fat, $p<0.001$, fiber, $p<0.001$ and interaction, $p=0.01$. $4 \mathrm{wk}$. post-switch: main effect of fat, $p<0.001$, fiber, $p<0.001$ and interaction, $p=$ 0.003. 5 wk. post-switch: main effect of fat, $p<0.001$, fiber, $p<0.001$, and interaction, $p=0.007$ ). Finally, LFC control was compared to all diets at 1-5 weeks after diet switching (Table 2). HFP and HFC diets were significantly different than LFC at all weeks measured, and LFC was significantly different only at 3 weeks post-switch. Table 3 demonstrates food intake.

\section{A HFC diet reduces locomotor activity which only a LFC or LFP diet corrects}

To compare the impact of LFC and HFC diets on baseline voluntary physical activity, locomotion was examined after 12 weeks (Table 4). To see if a dietary switch could improve locomotor activity of mice fed -HFC for 12 weeks,

Table 2 Body weight of mice switched from HFC to LFC, LFP, HFP and HFC

\begin{tabular}{|c|c|c|c|c|c|c|c|}
\hline \multirow[t]{2}{*}{ Starting Diet } & \multirow{2}{*}{$\begin{array}{l}\text { Baseline Body } \\
\text { Weight (g) }\end{array}$} & \multirow[t]{2}{*}{ Switch Diet } & \multicolumn{5}{|c|}{ Weeks Post-Switch Body Weight (g) } \\
\hline & & & 1 & 2 & 3 & 4 & 5 \\
\hline LFC & $23.99 \pm 0.30$ & - & $26.54 \pm 0.39$ & $26.94 \pm 0.40$ & $26.98 \pm 0.45$ & $27.29 \pm 0.53$ & $27.02 \pm 0.52$ \\
\hline \multirow[t]{4}{*}{ HFC } & $37.29 \pm 0.62^{\#}$ & LFP & $27.54 \pm 0.89^{c}$ & $26.92 \pm 0.59^{c}$ & $28.00 \pm 0.31^{c}$ & $28.88 \pm 0.44^{c}$ & $27.81 \pm 0.42^{c}$ \\
\hline & & LFC & $29.53 \pm 1.18^{c}$ & $28.78 \pm 0.97^{c}$ & $29.11 \pm 0.76^{\#, c}$ & $29.48 \pm 1.05^{c}$ & $29.00 \pm 1.07^{c}$ \\
\hline & & HFP & $35.22 \pm 1.34^{\#, a}$ & $35.41 \pm 1.17^{\#, a}$ & $35.94 \pm 1.16^{\#, a}$ & $36.96 \pm 1.37^{\#, a}$ & $37.93 \pm 1.48^{\#, a}$ \\
\hline & & $\mathrm{HFC}$ & $39.89 \pm 1.47^{\#, \mathrm{~b}}$ & $42.20 \pm 1.73^{\#, b}$ & $44.35 \pm 1.78^{\#, \mathrm{~b}}$ & $46.28 \pm 1.96^{\#, \mathrm{~b}}$ & $46.98 \pm 1.98^{\#, 6}$ \\
\hline
\end{tabular}

Mice were fed HFC as the starting diet for 12 weeks then switched to LFP, LFC, HFP, or HFC. Mice fed LFC as the starting diet were maintained on LFC as control. Results are expressed as mean \pm s.e.m.; $n=10-11$. Points without a common superscript are different $(p<0.05)$. \# indicates significance versus LFC control ( $p<0.05)$ 
Table 3 Food intake of mice switched from HFC to LFC, LFP, HFP and HFC

\begin{tabular}{|c|c|c|c|c|c|c|}
\hline \multirow[t]{2}{*}{ Starting Diet } & \multirow[t]{2}{*}{ Switch Diet } & \multicolumn{5}{|c|}{ Weeks Post-Switch Food Intake (g) } \\
\hline & & Diet Switch & 1 & 2 & 3 & 4 \\
\hline LFC Control & - & $3.7 \pm 0.1^{a}$ & $3.2 \pm 0.2^{\mathrm{a}}$ & $3.6 \pm 0.2^{\mathrm{a}, \mathrm{c}}$ & $4.0 \pm 0.2$ & $3.4 \pm 0.4$ \\
\hline \multirow[t]{4}{*}{ HFC } & LFP & $0.4 \pm 0.1^{\mathrm{b}}$ & $0.8 \pm 0.2^{b}$ & $3.4 \pm 0.1^{b}$ & $3.6 \pm 0.3$ & $3.0 \pm 0.1$ \\
\hline & LFC & $0.6 \pm 0.2^{b}$ & $1.5 \pm 0.4^{b}$ & $4.1 \pm 0.1^{c}$ & $3.7 \pm 0.2$ & $3.2 \pm 0.2$ \\
\hline & HFP & $4.3 \pm 0.4^{c}$ & $4.2 \pm 0.6^{\mathrm{a}}$ & $4.0 \pm 0.2^{a, c}$ & $4.1 \pm 0.3$ & $4.3 \pm 0.9$ \\
\hline & HFC & $3.7 \pm 0.1^{\mathrm{a}, \mathrm{c}}$ & $3.2 \pm 0.2^{\mathrm{a}}$ & $3.6 \pm 0.2^{a, b}$ & $4.0 \pm 0.2$ & $3.4 \pm 0.4$ \\
\hline
\end{tabular}

Mice were fed a LFC or HFC diet for 12 weeks (baseline) then either maintained on the LFC (LFC control) or switched from HFC to LFP, LFC, HFP, or HFC diets. Weekly measurements of daily food intake were collected each week post-switch for 4 weeks. Results are expressed as means \pm s.e.m.; $n=5-13$. Points without a common superscript are different $(P<0.05)$

mice were switched to HFP, LFC or LFP for 3 weeks (Table 4, main effects of fat, $p<0.001$, fiber, $p=0.94$ and interactions, $p=0.39$ ). At 3 weeks post-switch, HFP and HFC diets had significantly reduced locomotor activity compared to all low-fat diets. Table 4 also shows that the salutary effect of a low-fat diet on locomotor activity was present at 5 weeks (main effects of fat, $p<0.001$, fiber, $p=0.19$ and interactions, $p=0.59$ ).

\section{Switching from HFC to HFP, LFC, or LFP improves fasted blood glucose levels and blood glucose tolerance}

Fasting blood glucose was examined in mice that were fed a HFC diet for 12 weeks then switched to HFP, LFC, or LFP for 4 weeks. Mice switched to LFC or LFP had similar blood glucose levels compared to LFC control, while mice switched to HFP displayed lower blood glucose level than those fed the HFC diet (Fig. 1a, main effect of fat, $p=<0.001$, fiber, $p=0.10$ and interactions, $p=0.03 ;$ HFC v HFP, $233.00 \pm 9.64 \mathrm{mg} / \mathrm{dL}$ v $191.33 \pm$ $11.62 \mathrm{mg} / \mathrm{dL}, p=0.01 ;$ HFC v LFC, $233.00 \pm 9.64 \mathrm{mg} / \mathrm{dL}$ v $150.33 \pm 5.04 \mathrm{mg} / \mathrm{dL}, p<0.001 ;$ HFP v LFP, $191.33 \pm$ $11.62 \mathrm{mg} / \mathrm{dL}$ v $157.50 \pm 4.50 \mathrm{mg} / \mathrm{dL}, p=0.04 ; \mathrm{LFC} \mathrm{v} \mathrm{LFP}$, $150.33 \pm 5.04 \mathrm{mg} / \mathrm{dL} \quad \mathrm{v} 157.50 \pm 4.50 \mathrm{mg} / \mathrm{dL}, p=0.62$; HFC v LFC control, $233.00 \pm 9.64 \mathrm{mg} / \mathrm{dL}$ v $139.00 \pm$ $18.01 \mathrm{mg} / \mathrm{dL}, \mathrm{p}<0.001$; HFP v LFC control, $191.33 \pm$ $11.62 \mathrm{mg} / \mathrm{dL}$ v $139.00 \pm 18.01 \mathrm{mg} / \mathrm{dL}, \mathrm{p}=0.03 ; \mathrm{LFC} \mathrm{v}$ LFC control, $150.33 \pm 5.04 \mathrm{mg} / \mathrm{dL}$ v $139.00 \pm 18.01 \mathrm{mg} / \mathrm{dL}$, $p=0.50 ;$ LFP v LFC control, $157.50 \pm 4.50 \mathrm{mg} / \mathrm{dL} \quad \mathrm{v}$
$139.00 \pm 18.01 \mathrm{mg} / \mathrm{dL}, p=0.55)$. Fig $1 \mathrm{~b}$ demonstrates the impact of diet switch on glucose tolerance (main effect of fat, $p<0.001$, fiber, $\mathrm{p}=0.01$ and interactions, $p=0.02$; HFC v HFP, $105290.00 \pm 252.39 \mathrm{mg} / \mathrm{dL} / \mathrm{min}$ v 65,360.00 \pm $6386.17 \mathrm{mg} / \mathrm{dL} / \mathrm{min}, p=0.002$; HFC v LFC, $105290.00 \pm$ $252.39 \mathrm{mg} / \mathrm{dL} / \mathrm{min} \mathrm{v} 52,820.00 \pm 7827.08 \mathrm{mg} / \mathrm{dL} / \mathrm{min}$, $p<0.001 ;$ HFP v LFP, $65360.00 \pm 6386.17 \mathrm{mg} / \mathrm{dL} / \mathrm{min} \mathrm{v}$ $48,896.25 \pm 3483.75 \mathrm{mg} / \mathrm{dL} / \mathrm{min}, \quad p=0.10 ; \quad$ LFC v LFP, $52820.00 \pm 7827.09 \mathrm{mg} / \mathrm{dL} / \mathrm{min}$ v 48,896.25 $\pm 3483.75 \mathrm{mg} /$ $\mathrm{dL} / \mathrm{min}, \quad p=0.67$; HFC v LFC control, 105,290.00 \pm $252.39 \mathrm{mg} / \mathrm{dL} / \mathrm{min} \quad \mathrm{v} \quad 62,157.50 \pm 7695.9239 \mathrm{mg} / \mathrm{dL} /$ $\min , \quad p=0.003 ;$ HFP v LFC control 65,360.00 \pm $6386.17 \mathrm{mg} / \mathrm{dL} / \mathrm{min} \mathrm{v} 62,157.50 \pm 7695.92 \mathrm{mg} / \mathrm{dL} / \mathrm{min}$, $p=0.717$; LFC v LFC control, $52,820.00 \pm 7827.08 \mathrm{mg} /$ $\mathrm{dL} / \mathrm{min} \mathrm{v} \quad 62,157.50 \pm 7695.92 \mathrm{mg} / \mathrm{dL} / \mathrm{min}, \quad p=0.52$; LFP v LFC control, 48,896.25 $\pm 3483.75 \mathrm{mg} / \mathrm{dL} / \mathrm{min} \mathrm{v}$ $62,157.50 \pm 7695.92 \mathrm{mg} / \mathrm{dL} / \mathrm{min}, \quad p=0.49)$. Fig. $1 \mathrm{c}$ shows the blood glucose levels during the $180 \mathrm{~min}$ glucose tolerance test.

\section{Switching from HFC to HFP, LFC, or LFP decreases liver adiposity}

Mice fed a HFC diet for 12 weeks were switched to HFP, LFC, or LFP for 5 weeks (Fig. 2a and b, main effects of fat, $p<0.001$, fiber, $p=0.02$ and interactions, $p=0.18$; HFC v HFP, $54.65 \pm 4.27 \%$ v $43.63 \pm 1.32 \%$, p = 0.02; HFC v LFC, $54.65 \pm 4.27 \%$ v $34.30 \pm 1.61 \%, p<0.001$; HFP v LFP, $43.63 \pm 1.32 \%$ v $30.75 \pm 1.65 \%, p=0.01$; LFC v LFP,

Table 4 Impact on locomotion of switching from HFC to LFC, LFP, HFP and HFC

\begin{tabular}{|c|c|c|c|c|}
\hline \multirow[t]{2}{*}{ Starting Diet } & \multirow[t]{2}{*}{ Baseline } & \multirow[t]{2}{*}{ Switch Diet } & \multicolumn{2}{|c|}{ Weeks Post-Switch Locomotor Activity (cm) } \\
\hline & & & 3 & 5 \\
\hline LFC & $1502.66 \pm 80.20^{a}$ & - & $1533.83 \pm 111.39$ & $1834.80 \pm 133.71$ \\
\hline \multirow[t]{4}{*}{ HFC } & $1232.45 \pm 56.27^{b}$ & LFP & $1470.25 \pm 68.30^{a}$ & $1818.48 \pm 103.93^{a}$ \\
\hline & & LFC & $1404.95 \pm 90.70^{a}$ & $1904.84 \pm 102.28^{a}$ \\
\hline & & HFP & $924.76 \pm 86.23^{b_{1} \#}$ & $1136.88 \pm 132.45^{b, \#}$ \\
\hline & & HFC & $1001.79 \pm 81.53^{b, \#}$ & $1340.66 \pm 79.74^{b, \#}$ \\
\hline
\end{tabular}

Mice were fed HFC as the starting diet for 12 weeks then switched to LFP, LFC, HFP, or HFC. Mice fed LFC as the starting diet were maintained on LFC as control. Results are expressed as mean \pm s.e.m.; $n=10-11$. Points without a common superscript are different within each week post-switch ( $p<0.05)$. \# indicates significance versus LFC control within each week post switch $(p<0.05)$ 

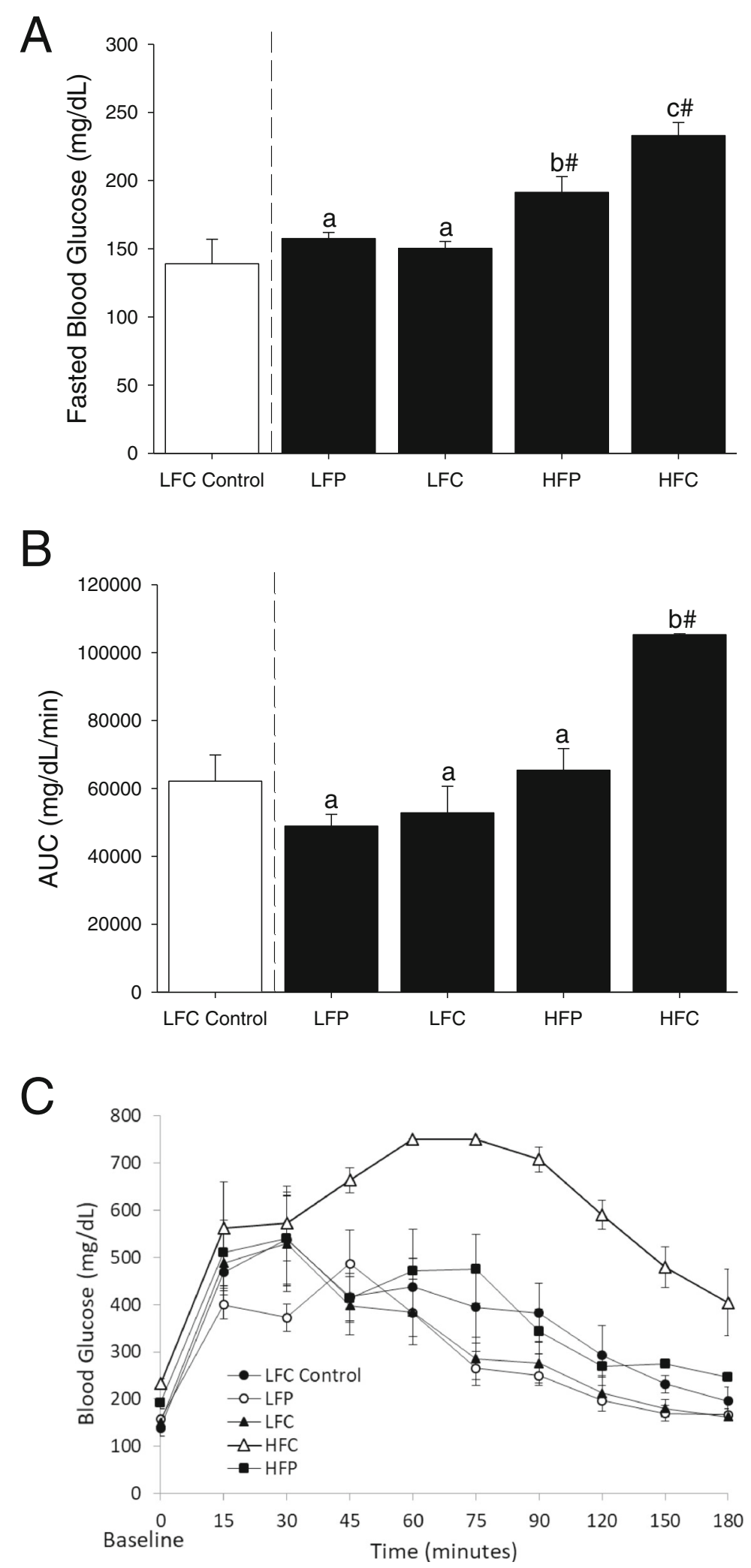

Fig. 1 (See legend on next page.) 
(See figure on previous page.)

Fig. 1 Switching from HFC to HFP, LFC, or LFP improves fasted blood glucose levels and blood glucose tolerance. (a) Mice were fed either LFC or HFC for 12 weeks and then HFC fed mice were switched to HFP, LFC or LFP for 4 weeks. Fasted ( 16 h) blood glucose was measured. Results are expressed as means \pm s.e.m.; $n=3$. Points without a common superscript are different $(p<0.05)$. \# indicates significance versus $L F C$ control $(p<0.05)$. (b) Mice were fed either LFC or HFC for 12 weeks and then HFC fed mice were switched to HFP, LFC or LFP for 4 weeks. Intraperitoneal glucose tolerance was measured over $180 \mathrm{~min}$. Results are expressed as means \pm s.e.m. of area under the curve (AUC) of blood glucose versus time; $n=3$. (c) Blood glucose levels from mice treated in (b). Results are expressed as means \pm s.e.m. of mg/dL of blood glucose; $n=3$. Points without a common superscript are different $(p<0.05)$. \# indicates significance versus LFC control $(p<0.05)$

$34.30 \pm 1.61 \%$ v 1.32 v $30.75 \pm 1.65 \%, p=0.35 ;$ HFC v LFC control, $54.65 \pm 4.27 \%$ v $27.37 \pm 1.12 \%, p<0.001$; HFP v LFC control, $43.63 \pm 1.32 \%$ v $27.37 \pm 1.12 \%, p<$ 0.001; LFC v LFC control, $34.30 \pm 1.61 \%$ v $27.37 \pm 1.12 \%$, $p=0.06 ;$ LFP v LFC control $30.75 \pm 1.65 \%$ v $27.37 \pm$ $1.12 \%, p=0.32)$.

\section{Discussion}

From 1850 to 1980, average life expectancy nearly doubled, increasing from about 39 years to about 75 years [60]. However, as the incidence of obesity accelerated in the 1970s, the rate of increased life expectancy slowed [6]. Some proposed that adverse health concerns associated
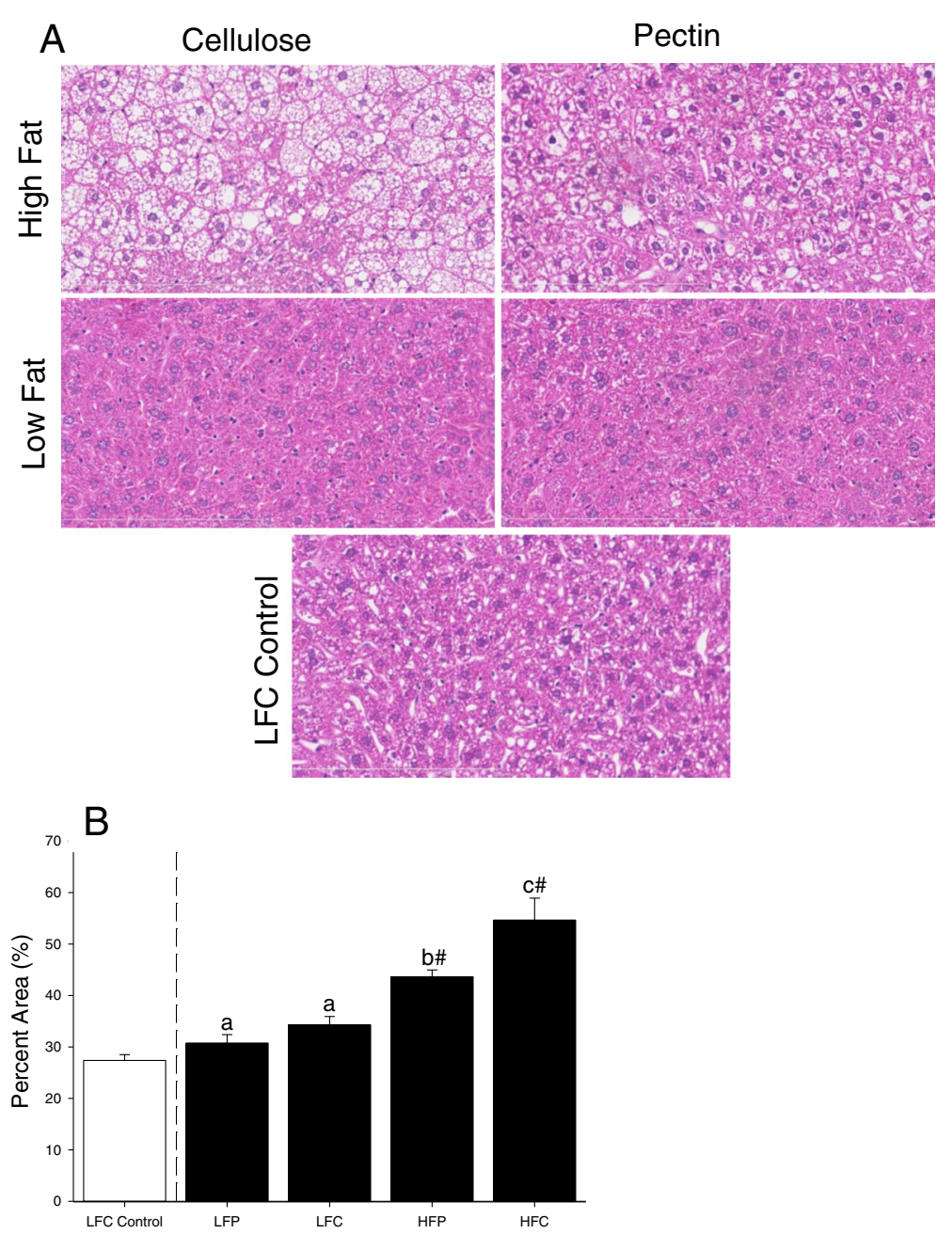

Fig. 2 Switching from HFC to HFP, LFC, or LFP decreased liver adiposity. Mice were fed either LFC or HFC for 12 weeks and then HFC fed mice were switched to HFP, LFC or LFP for 5 weeks. (a) Liver histology H\&E, representative, $n=3$. (b) Liver adiposity quantified by image analysis. Results are expressed as means \pm s.e.m.; $n=3$. Points without a common superscript are different $(p<0.05)$. \# indicates significance versus $L F C$ control $(p<0.05)$ 
with the obese state may be responsible for a proportion of decelerating average life expectancy [47, 56]. Clearly, obesity-linked co-morbidities like coronary heart disease, high blood pressure, stroke, type 2 diabetes, NAFLD and cancer support this contention [4]. To combat overnutrition-associated obesity, lifestyle changes such as calorie restriction and increased physical activity are advocated [52, 58], but these interventions are often of limited value outside the clinical setting [79]. For example, over $80 \%$ of people who intentionally lose $10+\%$ of body weight regain said weight within one year $[82,83]$. Some have compared battling obesity with the treatment of chronic disease [51], where initial weight loss interventions require a commitment to maintenance therapies [22]. Therefore, mediations that reduce weight and are realizable long term have clinical significance.

Overnutrition can trigger fat cell proliferation and differentiation $[43,73]$. Thus, in obesity, fat cells are not only larger but more numerous [7]. Interestingly, this change in fat cell physiology is associated with a decrease in the ability of mammals to lose weight [30, 49]. The high-fat diet (HFD) diet fed mouse used in this and many other studies $[9,61]$ is a well validated model of obesity and exemplifies many aspects of overnutrition-dependent human weight gain including the predisposition to NAFLD and glucose dyshomeostasis. Switching mice to a low-fat diet, regardless of fiber solubility, promoted over a $30 \%$ weight loss within one wk. Interestingly, this weight loss aligned mice previously fed a HFC for 12 wks with mice fed a LFC for 12 wks, indicating that these mice did not defend a HFD-induced weight gain as some animals and humans do [9]. These results also underscore the importance of decreased fat intake as an important way to reverse diet-induced obesity [39]. They also stress that dietary additives, like fiber, are no substitute for decreased caloric intake. Surprisingly, the HFP diet did promote weight loss and slow weight gain when compared to the HFC diet, suggesting that a diet high in soluble fiber may offset the weight-promoting effects of fat-based overnutrition.

Overall, obese mice demonstrate reduced spontaneous locomotion $[8,54]$. Furthermore, some dietary fibers are associated with improved physical performance of certain motor tasks [84]. As expected, mice fed HFC were less mobile than mice fed LFC. Like with weight, HFD-fed mice given a low fat diet for 3 wks returned to "baseline" locomotion when compared to mice fed solely a low-fat diet for 15 wks. Unlike weight, HFP did not demonstrate a normalizing effect because these mice continued to match their HFC counterparts in showing reduced spontaneous locomotion. In addition, weight loss did not appear to correlate linearly with restored locomotion. These results suggest that the weight loss due to pectin intake is not a consequence of increased physical activity but likely due to a reduction in the bioavailability or utilization of energy. In general, the mechanisms by which dietary fiber can contribute to weight loss include: delaying gastric emptying, reducing glucose diffusion and preventing fat absorption $[15,18,55]$. Thus, increasing intake of dietary soluble fiber may be an effective means to reduce energy accessibility/metabolism either as a monotherapy or as an adjuvant intervention with calorie restriction and/or increased caloric expenditure [44, 68].

The relationship between dietary fiber and diabetes has been extensively studied $[35,86]$. Many reports indicate that soluble fiber can significantly improve glycemic control for individuals with type 2 diabetes $[66,69]$. To this point, Adam et al. demonstrated that soluble fiber in combination with a HFD can positively also impact lipidaemia and insulinaemia [5]. In general, the impact of fiber on blood sugar depends on type and dose. In mice, for instance, $10 \%$ psyllium and $10 \%$ sugar cane fiber decreased fasting blood glucose when added to an HFD for 12 weeks as did $\beta$-Glucan [41]. In humans, however, muffins high in $\beta$-glucan and resistant starch lowered blood glucose more effectively than muffins containing low or medium $\beta$-glucan/resistant starch [41]. Overall, dietary fiber is thought to reduce blood glucose through an increase in satiety via increased mastication, calorie displacement, and decreased absorption of macronutrients [41]. Viscous fibers like pectin form gels in the intestine which appear to limit the interaction between luminal contents and digestive enzymes while thickening the unstirred water layer decreasing the diffusion and uptake of glucose [41]. As shown here, pectin (in the presence of high-fat) can lower fasting blood glucose when compared to cellulose. Despite the above, how pectin improves glucose homeostasis is still not clear, but appears partially delinked from weight regulation. As the AUC data show, HFP completely normalized glucose clearance when compared to HFC.

When weight is evaluated, HFP mitigated fat-dependent gain by $50 \%$. In general, dietary supplementation with fiber produces inconsistent results when weight loss is examined [20,34, 41]. Again, gel formation in the intestine may be key to pectin-mediated reduced weight gain. The ability of gel-forming fibers, like pectin, to bind bile acids and micelle components, such as monoglycerides, free fatty acids and cholesterol decrease fat absorption in the gut [41]. Interestingly, NAFLD induced by a high-fat diet was also reduced when pectin replaced cellulose. Like weight, pectin appeared to mitigate fatty liver by about $50 \%$. Fermentable fibers like pectin can impact the expression of acetyl-CoA carboxylase which is the rate-limiting enzyme in lipogenesis [41]. As example, a $10 \mathrm{wk}$. course of 
Plantago ovata increased AMPK phosphorylation reducing activity of acetyl-CoA carboxylase in obese rats to that in lean rats [29]. Additionally, short chain fatty acids due to gut fermentation of fermentable fibers appear to activate hepatic AMPK [41]. Such findings support the important role of soluble when compared to insoluble fiber when attempting to use diet as a first line treatment for pre-diabetes $[19,48]$, but underscores its limitation as a weight loss therapy.

\section{Conclusion}

In humans, weight loss is difficult to realize and maintain [21]. Even effective procedural interventions like bariatric surgery often lose efficiency long-term [31, 59]. As shown here, palatable dietary interventions that can slow or prevent overnutrition-dependent weight gain are achievable in mice. Whether such methods can be translated to humans remains to be determined, since fermentable and gel-forming fibers may generate abdominal discomfort and oily/watery stools.

\section{Abbreviations}

H\&E: hematoxylin and eosin; HFC: $60 \%$ fat + 10\% cellulose diet; HFP: $60 \%$ fat $+10 \%$ pectin diet; LFC: $10 \%$ fat $+10 \%$ cellulose diet; LFP: $10 \%$ fat $+10 \%$ pectin diet

\section{Funding}

This research was supported by the National Institutes of Health: DK064862 and DK059802 to the Division of Nutritional Sciences as a Ruth L. Kirchstein National Research Service Award Predoctoral Fellowship to GSC.

\section{Availability of data and materials}

Data sharing not applicable as no datasets were generated nor analyzed.

\begin{abstract}
Author's contributions
LKM, GGF, GSC, and MLM participated in designing the experiments. LKM $J K B$, and RW conducted the experiments. JKB, GSC and AET analyzed the data. JKB, GGF, GSC and AET wrote the manuscript. All authors read and approved the final manuscript.
\end{abstract}

\section{Ethics approval}

Animal use was conducted in accordance with Institutional Animal Care and Use Committee approved protocols at the University of Illinois.

\section{Consent for publication}

Not applicable.

\section{Competing interests}

The authors declare that they have no competing interests.

\section{Publisher's Note}

Springer Nature remains neutral with regard to jurisdictional claims in published maps and institutional affiliations.

\section{Author details}

'Department of Pathology, Program in Integrative Immunology and Behavior, University of Illinois, Urbana, IL, USA. ${ }^{2}$ Division of Nutritional Sciences, University of Illinois, Urbana, IL, USA. ${ }^{3}$ Department of Animal Sciences, University of Illinois, Urbana, IL, USA. ${ }^{4}$ Department of Pathology, College of Medicine, University of Illinois at Urbana Champaign, 506 South Mathews Avenue, Urbana, IL 61801, USA.
Received: 29 January 2018 Accepted: 25 July 2018

Published online: 06 August 2018

\section{References}

1. (AACC) AAoCC. The Definition of Dietary Fiber. Cereal Foods World. 2001:112-26.

2. (NCD-RisC) NRFC. Trends in adult body-mass index in 200 countries from 1975 to 2014: a pooled analysis of 1698 population-based measurement studies with 19.2 million participants. Lancet. 2016:387(10026):1377-96.

3. $(\mathrm{NIH}) \mathrm{NloH}$. Quantifying Stained Liver Tissue. https://imagej.nih.gov/ij/docs/ examples/stained-sections/index.html.

4. Abdelaal M, le Roux CW, Docherty NG. Morbidity and mortality associated with obesity. Ann Transl Med. 2017:5(7):161.

5. Adam CL, Thomson LM, Williams PA, Ross AW. Soluble fermentable dietary fibre (pectin) decreases caloric intake, adiposity and Lipidaemia in high-fat diet-induced obese rats. PLoS One. 2015;10(10):e0140392. Epub 2015/10/08

6. Bell FC, Miller ML. Life tables for the United States social security area, 1900-2100. Social Security Administration; 2002.

7. Björntorp P, Sjöström L. Number and size of adipose tissue fat cells in relation to metabolism in human obesity. Metabolism. 1971;20(7):703-13.

8. Bjursell M, Gerdin AK, Lelliott CJ, Egecioglu E, Elmgren A, Törnell J, Oscarsson J, Bohlooly-Y M. Acutely reduced locomotor activity is a major contributor to western diet-induced obesity in mice. Am J Physiol Endocrinol Metab. 2008;294(2):E251-60. Epub 2007/11/20

9. Buettner R, Schölmerich J, Bollheimer LC. High-fat diets: modeling the metabolic disorders of human obesity in rodents. Obesity (Silver Spring). 2007;15(4):798-808.

10. Chen Q, Zhu L, Tang Y, Zhao Z, Yi T, Chen H. Preparation-related structural diversity and medical potential in the treatment of diabetes mellitus with ginseng pectins. Ann N Y Acad Sci. 2017;1401(1):75-89. Epub 2017/08/01

11. Chiu GS, Chatterjee D, Darmody PT, Walsh JP, Meling DD, Johnson RW, Freund GG. Hypoxia/reoxygenation impairs memory formation via adenosinedependent activation of caspase 1. J Neurosci. 2012;32(40):13945-55.

12. Chutkan R, Fahey G, Wright WL, McRorie J. Viscous versus nonviscous soluble fiber supplements: mechanisms and evidence for fiber-specific health benefits. J Am Acad Nurse Pract. 2012;24(8):476-87.

13. Colditz GA, Willett WC, Rotnitzky A, Manson JE. Weight gain as a risk factor for clinical diabetes mellitus in women. Ann Intern Med. 1995;122(7):481-6.

14. Danaei G, Finucane MM, Lin JK, Singh GM, Paciorek CJ, Cowan MJ, Farzadfar F, Stevens GA, Lim SS, Riley LM, Ezzati M. Pressure GBoMRFoCDCGB. National, regional, and global trends in systolic blood pressure since 1980: systematic analysis of health examination surveys and epidemiological studies with 786 country-years and 5.4 million participants. Lancet. 2011; 377(9765):568-77. Epub 2011/02/03

15. Daou C, Zhang H. Functional and physiological properties of total, soluble, and insoluble dietary fibres derived from defatted rice bran. J Food Sci Technol. 2014;51(12):3878-85. Epub 2013/01/25

16. de Carvalho VF, Guedes Cocate P, Gonçalves Pereira L, de Cássia Gonçalves Alfenas $R$. The role of hyperglycemia in the induction of oxidative stress and inflammatory process. Nutr Hosp. 2012;27(5):1391-8.

17. De Pergola G, Silvestris F. Obesity as a major risk factor for cancer. J Obes. 2013;2013:291546. Epub 2013/08/29

18. de Vries J, Miller PE, Verbeke K. Effects of cereal fiber on bowel function: a systematic review of intervention trials. World J Gastroenterol. 2015;21(29): 8952-63.

19. Del Toma E, Lintas C, Clementi A, Marcelli M. Soluble and insoluble dietary fibre in diabetic diets. Eur J Clin Nutr. 1988;42(4):313-9.

20. Delargy HJ, O'Sullivan KR, Fletcher RJ, Blundell JE. Effects of amount and type of dietary fibre (soluble and insoluble) on short-term control of appetite. Int J Food Sci Nutr. 1997:48(1):67-77.

21. DerSarkissian M, Bhak RH, Huang J, Buchs S, Vekeman F, Smolarz BG, Brett J, Ganguly R, Duh MS. Maintenance of weight loss or stability in subjects with obesity: a retrospective longitudinal analysis of a real-world population. Curr Med Res Opin. 2017;33(6):1105-10. Epub 2017/04/03

22. Dixon JB. Obesity in 2015: advances in managing obesity. Nat Rev Endocrinol. 2016;12(2):65-6.

23. Dubuc PU. The development of obesity, hyperinsulinemia, and hyperglycemia in Ob/Ob mice. Metabolism. 1976;25(12):1567-74.

24. Eckel RH, Kahn SE, Ferrannini E, Goldfine AB, Nathan DM, Schwartz MW, Smith RJ, Smith SR. Obesity and type 2 diabetes: what can be unified 
and what needs to be individualized? J Clin Endocrinol Metab. 2011;96(6):1654-63.

25. Farzadfar F, Finucane MM, Danaei G, Pelizzari PM, Cowan MJ, Paciorek CJ, Singh GM, Lin JK, Stevens GA, Riley LM, Ezzati M. (cholesterol) GBoMRFoCDCG. National, regional, and global trends in serum total cholesterol since 1980: systematic analysis of health examination surveys and epidemiological studies with 321 country-years and 3.0 million participants. Lancet. 2011;377(9765):578-86. Epub 2011/02/03

26. Fernandes J, Su W, Rahat-Rozenbloom S, Wolever TM, Comelli EM. Adiposity, gut microbiota and faecal short chain fatty acids are linked in adult humans. Nutr Diabetes. 2014:4:e121. Epub 2014/06/30

27. Finucane MM, Stevens GA, Cowan MJ, Danaei G, Lin JK, Paciorek CJ, Singh GM, Gutierrez HR, Lu Y, Bahalim AN, Farzadfar F, Riley LM, Ezzati M. Index GBoMRFoCDCGBM. National, regional, and global trends in body-mass index since 1980: systematic analysis of health examination surveys and epidemiological studies with 960 country-years and 9.1 million participants. Lancet. 2011;377(9765):557-67. Epub 2011/02/03

28. Furukawa S, Fujita T, Shimabukuro M, Iwaki M, Yamada Y, Nakajima Y, Nakayama O, Makishima M, Matsuda M, Shimomura I. Increased oxidative stress in obesity and its impact on metabolic syndrome. J Clin Invest. 2004;114(12):1752-61.

29. Galisteo M, Moron R, Rivera L, Romero R, Anguera A, Zarzuelo A. Plantago ovata husks-supplemented diet ameliorates metabolic alterations in obese Zucker rats through activation of AMP-activated protein kinase. Comparative study with other dietary fibers Clin Nutr. 2010;29:261.

30. Greenway FL. Physiological adaptations to weight loss and factors favouring weight regain. Int J Obes. 2015;39(8):1188-96. Epub 2015/04/21

31. Herman KM, Carver TE, Christou NV, Andersen RE. Keeping the weight off: physical activity, sitting time, and weight loss maintenance in bariatric surgery patients 2 to 16 years postsurgery. Obes Surg. 2014;24(7):1064-72

32. Hooper L, Abdelhamid A, Bunn D, Brown T, Summerbell CD, Skeaff CM. Effects of total fat intake on body weight. Cochrane Database Syst Rev. 2015;8:CD011834.

33. Howarth NC, Saltzman E, Roberts SB. Dietary fiber and weight regulation. Nutr Rev. 2001;59(5):129-39.

34. Isken F, Klaus S, Osterhoff M, Pfeiffer AF, Weickert MO. Effects of long-term soluble vs. insoluble dietary fiber intake on high-fat diet-induced obesity in C57BL/6J mice. J Nutr Biochem. 2010;21(4):278-84.

35. Ismaiel M, Yang H, Min C. Dietary fiber role in type 2 diabetes prevention. 2016. p. 961-975.

36. Jakobsdottir G, Xu J, Molin G, Ahrné S, Nyman M. High-fat diet reduces the formation of butyrate, but increases succinate, inflammation, liver fat and cholesterol in rats, while dietary fibre counteracts these effects. PLoS One. 2013:8(11):e80476.

37. Jenkins DJ, Leeds AR, Gassull MA, Cochet B, Alberti GM. Decrease in postprandial insulin and glucose concentrations by guar and pectin. Ann Intern Med 1977:86(1):20-23. PubMed PMID: 835924

38. Johnson DR, O'Connor JC, Hartman ME, Tapping RI, Freund GG. Acute hypoxia activates the neuroimmune system, which diabetes exacerbates. J Neurosci. 2007;27(5):1161-6.

39. Johnston BC, Kanters S, Bandayrel K, Wu P, Naji F, Siemieniuk RA, Ball GD, Busse JW, Thorlund K, Guyatt G, Jansen JP, Mills EJ. Comparison of weight loss among named diet programs in overweight and obese adults: a meta-analysis. JAMA. 2014;312(9):923-33.

40. Jumpertz R, Le DS, Turnbaugh PJ, Trinidad C, Bogardus C, Gordon JI, Krakoff J. Energy-balance studies reveal associations between gut microbes, caloric load, and nutrient absorption in humans. Am J Clin Nutr. 2011;94(1):58-65. Epub 2011/05/04

41. Kaczmarczyk MM, Miller MJ, Freund GG. The health benefits of dietary fiber: beyond the usual suspects of type 2 diabetes mellitus, cardiovascular disease and colon cancer. Metabolism. 2012;61(8):1058-66. Epub 2012/03/07

42. Kaline K, Bornstein SR, Bergmann A, Hauner H, Schwarz PE. The importance and effect of dietary fiber in diabetes prevention with particular consideration of whole grain products. Horm Metab Res. 2007:39(9):687-93.

43. Klyde BJ, Hirsch J. Increased cellular proliferation in adipose tissue of adult rats fed a high-fat diet. J Lipid Res. 1979;20(6):705-15.

44. Lattimer JM, Haub MD. Effects of dietary fiber and its components on metabolic health. Nutrients. 2010;2(12):1266-89.
45. Lavin DN, Joesting JJ, Chiu GS, Moon ML, Meng J, Dilger RN, Freund GG. Fasting induces an anti-inflammatory effect on the neuroimmune system which a high-fat diet prevents. Obesity (Silver Spring). 2011;19(8):1586-94.

46. Li BW, Andrews KW, Pehrssonw PR. Individual Sugars, Soluble, and Insoluble Dietary Fiber Contents of 70 High Consumption Foods. J Food Consump and Analysis. 2002:715-23.

47. Ludwig DS. Lifespan weighed down by diet. JAMA. 2016;315(21):2269-70.

48. Ma M, Mu T. Anti-diabetic effects of soluble and insoluble dietary fibre from deoiled cumin in low-dose streptozotocin and high glucose-fat dietinduced type 2 diabetic rats. J Funct Foods. 2016:186-96.

49. MacLean PS, Higgins JA, Giles ED, Sherk VD, Jackman MR. The role for adipose tissue in weight regain after weight loss. Obes Rev. 2015;16(Suppl 1):45-54.

50. Marlett JA. Content and composition of dietary fiber in 117 frequently consumed foods. J Am Diet Assoc. 1992:92(2):175-86.

51. Middleton KM, Patidar SM, Perri MG. The impact of extended care on the long-term maintenance of weight loss: a systematic review and metaanalysis. Obes Rev. 2012;13(6):509-17. Epub 2011/12/29

52. Minor RK, Allard JS, Younts CM, Ward TM, de Cabo R. Dietary interventions to extend life span and health span based on calorie restriction. J Gerontol A Biol Sci Med Sci. 2010;65(7):695-703. Epub 2010/04/06

53. Moore JB. Non-alcoholic fatty liver disease: the hepatic consequence of obesity and the metabolic syndrome. Proc Nutr Soc. 2010;69(2):211-20. Epub 2010/02/17

54. Moretto TL, Benfato ID, de Carvalho FP, Barthichoto M, Le Sueur-Maluf $L$, de Oliveira CAM. The effects of calorie-matched high-fat diet consumption on spontaneous physical activity and development of obesity. Life Sci. 2017;179:30-6. Epub 2017/04/25

55. Munakata A, Iwane S, Todate M, Nakaji S, Sugawara K. Effects of dietary fiber on gastrointestinal transit time, fecal properties and fat absorption in rats. Tohoku J Exp Med. 1995;176(4):227-38.

56. Olshansky SJ, Passaro DJ, Hershow RC, Layden J, Carnes BA, Brody J, Hayflick L, Butler RN, Allison DB, Ludwig DS. A potential decline in life expectancy in the United States in the 21st century. N Engl J Med. 2005;352(11):1138-45.

57. Otles S, Ozgoz S. Health effects of dietary fiber. Acta Sci Pol Technol Aliment. 2014;13(2):191-202.

58. Pescatello LS, VanHeest JL. Physical activity mediates a healthier body weight in the presence of obesity. Br J Sports Med. 2000;34(2):86-93.

59. Puzziferri N, Roshek TB, Mayo HG, Gallagher R, Belle SH, Livingston EH Long-term follow-up after bariatric surgery: a systematic review. JAMA. 2014;312(9):934-42.

60. Roser M. Life expectancy.Published online at OurWorldlnData.org; 2017.

61. Rossmeisl M, Rim JS, Koza RA, Kozak LP. Variation in type 2 diabetes--related traits in mouse strains susceptible to diet-induced obesity. Diabetes. 2003;52(8):1958-66.

62. Sarma S, Zaric GS, Campbell MK, Gilliland J. The effect of physical activity on adult obesity: evidence from the Canadian NPHS panel. Econ Hum Biol. 2014;14:1-21.

63. Sharma BR, L. N, Dhuldhoya NC, Merchant SU, Merchant UC. An Overview on Pectins. June-July ed: Times Food Processing Journal; 2006. p. 44-51.

64. Sherry CL, Kim SS, Dilger RN, Bauer LL, Moon ML, Tapping RI, Fahey GC, Tappenden KA, Freund GG. Sickness behavior induced by endotoxin can be mitigated by the dietary soluble fiber, pectin, through up-regulation of IL-4 and Th2 polarization. Brain Behav Immun. 2010;24(4):631-40.

65. Silva DC, Freitas AL, Pessoa CD, Paula RC, Mesquita JX, Leal LK, Brito GA, Gonçalves DO, Viana GS. Pectin from Passiflora edulis shows antiinflammatory action as well as hypoglycemic and hypotriglyceridemic properties in diabetic rats. J Med Food. 2011;14(10):1118-26.

66. Silva FM, Kramer CK, de Almeida JC, Steemburgo T, Gross JL, Azevedo MJ. Fiber intake and glycemic control in patients with type 2 diabetes mellitus: a systematic review with meta-analysis of randomized controlled trials. Nutr Rev. 2013;71(12):790-801.

67. Siro I, Plackett D. Microfibrillated cellulose and new nanocomposite materials: a review. Cellulose. 2010:459-94.

68. Slavin JL. Dietary fiber and body weight. Nutrition. 2005;21(3):411-8.

69. Song Y-J, Sawamura M, Ikeda K, Igawa S, Yamori Y. Soluble dietary fibre improves insulin sensitivity by increasing muscle Glut-4 content in strokeprone spontaneously hypertensive rats. Clin Experiment Pahrmacol Physiol. 2000:27:41. 
70. Sousa RVRB, Guedes MIF, Marques MMM, Viana DA, Goes da Silva IN, PAS R, IGP V. Hypoglycemic effect of new pectin isolated from passiflora glandulosa cav in alloxan-induced diabetic mice. World J Pharma Pharmaceutic Sci. 2015:1571-86.

71. Suzuki Y, Tsunoda H, Kimura T, Yamauchi H. BMI change and abdominal circumference are risk factors for breast cancer, even in Asian women. Breast Cancer Res Treat. 2017; Epub 2017/08/31

72. Tai MM. A mathematical model for the determination of total area under glucose tolerance and other metabolic curves. Diabetes Care. 1994;17(2): $152-4$.

73. Tchoukalova YD, Votruba SB, Tchkonia T, Giorgadze N, Kirkland JL, Jensen MD. Regional differences in cellular mechanisms of adipose tissue gain with overfeeding. Proc Natl Acad Sci U S A. 2010;107(42):18226-31.

74. Thakur BR, Singh RK, Handa AK. Chemistry and uses of pectin--a review. Crit Rev Food Sci Nutr. 1997;37(1):47-73.

75. Towers AE, York JM, Baynard T, Gainey SJ, Freund GG. Mouse testing methods in psychoneuroimmunology 2.0: measuring behavioral responses. Methods Mol Biol. 2018;1781:221-58.

76. Tucker LA, Thomas KS. Increasing total fiber intake reduces risk of weight and fat gains in women. J Nutr. 2009;139(3):576-81.

77. Turnbaugh PJ, Ley RE, Mahowald MA, Magrini V, Mardis ER, Gordon JI. An obesity-associated gut microbiome with increased capacity for energy harvest. Nature. 2006;444(7122):1027-31.

78. Vigne JL, Lairon D, Borel P, Portugal H, Pauli AM, Hauton JC, Lafont H. Effect of pectin, wheat bran and cellulose on serum lipids and lipoproteins in rats fed on a low- or high-fat diet. Br J Nutr. 1987;58(3):405-13.

79. Wadden TA, Volger S, Tsai AG, Sarwer DB, Berkowitz RI, Diewald LK, Carvajal $\mathrm{R}$, Moran $\mathrm{CH}$, Vetter M, Group P-UR. Managing obesity in primary care practice: an overview with perspective from the POWER-UP study. Int J Obes. 2013;37(Suppl 1):S3-11.

80. Wanders AJ, van den Borne JJ, de Graaf C, Hulshof T, Jonathan MC, Kristensen M, Mars M, Schols HA, Feskens EJ. Effects of dietary fibre on subjective appetite, energy intake and body weight: a systematic review of randomized controlled trials. Obes Rev. 2011;12(9):724-39.

81. Wellen KE, Hotamisligil GS. Inflammation, stress, and diabetes. J Clin Invest. 2005;115(5):1111-9. https://doi.org/10.1172/JC125102.

82. Wing RR, Hill JO. Successful weight loss maintenance. Annu Rev Nutr. 2001;21:323-41.

83. Wing RR, Phelan S. Long-term weight loss maintenance. Am J Clin Nutr. 2005;82(1 Suppl):222S-5S.

84. Wu IC, Chang HY, Hsu CC, Chiu YF, Yu SH, Tsai YF, Shen SC, Kuo KN, Chen CY, Liu K, Lee MM, Hsiung CA. Association between dietary fiber intake and physical performance in older adults: a nationwide study in Taiwan. PLoS One. 2013;8(11):e80209.

85. Xu ZJ, Fan JG, Ding XD, Qiao L, Wang GL. Characterization of high-fat, dietinduced, non-alcoholic steatohepatitis with fibrosis in rats. Dig Dis Sci. 2010;55(4):931-40. Epub 2009/05/21

86. Yao B, Fang H, Xu W, Yan Y, Xu H, Liu Y, Mo M, Zhang H, Zhao Y. Dietary fiber intake and risk of type 2 diabetes: a dose-response analysis of prospective studies. Eur J Epidemiol. 2014;29(2):79-88. Epub 2014/01/05

87. York JM, Blevins NA, Meling DD, Peterlin MB, Gridley DS, Cengel KA, Freund GG. The biobehavioral and neuroimmune impact of low-dose ionizing radiation. Brain Behav Immun. 2012;26(2):218-27.

\section{Ready to submit your research? Choose BMC and benefit from:}

- fast, convenient online submission

- thorough peer review by experienced researchers in your field

- rapid publication on acceptance

- support for research data, including large and complex data types

- gold Open Access which fosters wider collaboration and increased citations

- maximum visibility for your research: over $100 \mathrm{M}$ website views per year

At BMC, research is always in progress.

Learn more biomedcentral.com/submissions 